\title{
Genetic Perspective of the Congenital Hypothyroidism, ATXN10 a Candidate Gene
}

\author{
Sergio Alberto Ramirez-Garcia ${ }^{1,2 *}$, Diana \\ García Cruz ${ }^{3}$, Luis J avier Flores-Alvarado 4 , Luz \\ Margarita Baltzar-Rodriguez ${ }^{2}$, Mauro Alberto \\ Sánchez-Hernández ${ }^{5}$ and Rubén Alexander \\ Elzaurdin-Mora ${ }^{6}$ \\ ${ }^{1}$ Universidad de la Sierra Sur, México \\ ${ }^{2}$ Medicals in Medical Sciences, University of Colima, \\ Mexico \\ ${ }^{3}$ Institute of Human Genetics, University of Guadalajara, \\ Mexico \\ ${ }^{4}$ Department of Molecular Biology, University of \\ Guadalajara, Mexico \\ ${ }^{5}$ CA-Emprendedores, Benito J uárez Autonomous \\ University of Oaxaca, Mexico \\ ${ }^{6}$ International Center of Health, The Pradera, Habana, \\ Cuba \\ *Corresponding author: Sergio A Ramirez-Garcia, \\ Universidad de la Sierra Sur, México, Guillermo Rojas \\ Mijangos, S/N. Cd. Universitaria. Miahuatlán de Porfirio \\ Díaz, Oaxaca. Mail Box: 70800. México
}

Received: August 31, 2018; Accepted: September 07, 2018; Published: September 14, 2018

\section{Editorial}

Congenital hypothyroidism is a public health problem in many Latin American countries. Its consequences such as mental and psychomotor retardation are important but if diagnosed early can be preventable. With these considerations, neonatal screening programs have been implemented in the newborn to allow its detection; blood TSH quantization of umbilical cord or heel. Another strategy is the search for genetic susceptibility markers. Researchers have focused in this sense on three axes;

1. Molecular alterations related to thyroid dysgenesis (mutations in FOXE1, NKX2.1, PAX8).

2. Molecular alterations related to thyroid dyshormonogenesis, the genes related to this pathway are divided in to several categories: a) Poor response to TSH due to alterations in the TSH gene, or mutations in the GNAS1 gene, b) Defects in the transport of iodine at the basal membrane due to mutations in the SLC5A and the SLC26A4 gene, c) Defects in the synthesis of thyroglobulin due to mutations in the TG gene, d) Defects in the organization of iodine by mutations in the thyroperoxidase gene (TPO) or in THOX1 genes and THOX2, e) Defects in the dehalogenase gene.

3. Molecular alterations related to central cause of hypothyroidism; mutations in the genes HESX1, LHX3, PROP1 and POU1F1.4. Molecular alterations related to peripheral hypothyroidism caused by mutations in thyroid hormone receptors TSHR A and B or by alterations in the mechanism of deiodinases, especially in the genes for DUOX2 and DUOXA2) responsible for the conversion of T4 to T3 [1-4].

In this sense, the ATXN10 is a candidate gene for cases of dyshormonogenesis, considering that it is an important gene in development, its deficiency becomes lethal in embryogenesis, it is highly expressed in thyroid tissue (Genecards ID: GC22P045673). The gene has a repeated pentanucleotide which relates to the expression of ataxin 10. ATXN10 gene may be a marker particularly if agenesis, athyireosis, Thyroid hypoplasia and Thyroid hemiagenesis or could be involved in the phenotype of various syndromic hypothyroidism; Bamforth-Lazarus syndrome (Albright hereditary osteodystrophy, Pendred syndrome, ectodermal dysplasia with ciliary dyskinesia, Hypothyroidism-dimorphism, postaxial polydactyly, intellectual deficit syndrome Kocher-Duty-Semilange and Obesity-colitishypothyroidism- hypertrophy, cardiac-developmental delay, which should be undertaken by researchers in the biomedical area in the following years, since it is a field that is little explored in Mexico as well as worldwide.

\section{References}

1. Topete-González LR, Ramirez-Garcia SA, Macías-López GG, TroyoSanromán R, Ramos-Ramírez IM, Elizondo-Rueda ME, et al. Hypothyroidism incidence and thyrotropin serum levels in newborns. Rev Med Inst Mex Seguro Soc. 2013; 51: 136-141.

2. Castillón PE. Congenital hypothyroidism. Bol Med Hosp Infant Mex. 2015; 72: $140-148$

3. Pinzón-Serrano E, Morán-Barroso V, Coyote-Estrada N. Molecular bases of congenital hypothyroidism. Bol Med Hosp Infant Mex. 2006; 63: 351-359.

4. Ataxin 10 gene. Genecards. 2018
Annals Thyroid Res - Volume 4 Issue 2 - 2018

Submit your Manuscript | www.austinpublishinggroup.com

Ramirez-Garcia et al. (C) All rights are reserved
Citation: Ramirez-Garcia SA, Cruz-Garcia D, Flores-Alvarado LJ, Baltzar-Rodriguez LM, Sánchez-Hernández MA, Elzaurdin-Mora RA. Genetic Perspective of the Congenital Hypothyroidism, ATXN10 a Candidate Gene. Annals Thyroid Res. 2018; 4(2): 155-155. 